\title{
CYTOTOXICITY AND GENOTOXICITY OF SOIL IN SHUMEN CITY PARK
}

\author{
Teodora Koynova, ${ }^{1}$ Vanya Koleva, ${ }^{2}$ Asya Dragoeva, ${ }^{3}$ Ivayla Kuleva ${ }^{4}$
}

\begin{abstract}
Sedentary lifestyle has become a great concern to human health. City parks play a great role in the solution of this problem, but exposure to urban pollutants leads to the necessity to monitor environmental quality.

Purpose of Study The aim of the study was to evaluate the possible cytotoxicity and genotoxicity of soil samples collected from Shumen city park using Allium cepa L.-test.

Methods The following microscopic parameters were used: mitotic index, index of each phase of mitotic division, mitotic abnormalities and interphase cells with micronuclei or two nuclei.

Findings and Results The decline of the mitotic activity and changes in the proportion of mitotic phases indicate soil cytotoxicity. Various mitotic abnormalities and binucleated cells revealed genotoxicity.

Conclusions and Recommendations Established cytotoxicity and genotoxicity of soil revealed a potential health risk to park users. Further analyses should be provided, since positive results from Allium-test serve as an alarm.
\end{abstract}

UDC Classification: 502/504; DOI: http://dx.doi.org/10.12955/cbup.v5.1086

Keywords: Shumen city park, Allium-test, soil cytotoxicity and genotoxicity

\section{Introduction}

More than a half of mankind now lives in towns. A sedentary lifestyle has become a great concern to human health (Owen et al., 2010). Physical inactivity is a major factor for various diseases. City parks play a great role in the solution of this problem. Numerous studies have documented the positive influence of urban green spaces on physical and mental health (Kabisch and Haase, 2013). On the other hand, being located in the towns, parks are exposed to various pollutants due primarily to traffic, industrial and domestic emissions (Galušková et al., 2011). Park demand determines the necessity to monitor environmental quality. Air pollution is deeply studied, but soil pollution has remained in the background (Science Communication Unit, 2013). It should be noted that citizens have direct contact with soils using recreational areas and adverse effects are generally associated with inhalation of dust (Moosavi and Zarasvandi, 2009). Exposure to contaminated soils may pose a health risk, especially for children because of the additional soil-hand-mouth pathway (Ljung et al., 2006).

Recently, a lot of studies have been focused on urban soil pollution (Karim et al., 2014; Luo et al., 2012; Yang and Zhang, 2015). The standard analytical approach is not appropriate for evaluation of health risk of complex mixtures like soil - bioassays are useful in such studies (Soodan et al., 2012). Special attention has been paid to soil mutagens (Monarca et al., 2002). A lot of studies have established genotoxic pollutants in soils (Watanabe and Hirayama, 2001; White and Claxton, 2004). Higher plant bioassays are used as genetic models for testing toxicity of various environmental contaminants (Chahal et al., 2014; Corneanu et al., 2009). The Allium cepa-test has been widely used to study of cytotoxicity and genotoxicity of different pollutants (Fiskesjö, 1993; Tedesco and Laughinghouse IV, 2012; Leme and Marin-Morales, 2009).

The present study is focused on an urban recreational area - Shumen city park (Bulgaria). A "site by site" approach is recommended in such studies, because of specific features of the particular site (Science Communication Unit, 2013). In the case of present study, the park is located near the center of the town of Shumen - a medium-sized city, an important transport hub with well-developed light industry. The park provides a variety of functions including spaces for relaxing, meeting friends, play areas for children, etc.

The aim of this study was to evaluate the possible cytotoxicity and genotoxicity of soil samples collected from Shumen city park using Allium cepa-test.

\footnotetext{
${ }^{1}$ Faculty of Natural Sciences, Konstantin Preslavski University of Shumen, Bulgaria, t.koynova@abv.bg

${ }^{2}$ Faculty of Natural Sciences, Konstantin Preslavski University of Shumen, Bulgaria vanyakolleva@ gmail.com

${ }^{3}$ Faculty of Natural Sciences, Konstantin Preslavski University of Shumen, Bulgaria a.dragoeva@shu.bg

${ }^{4}$ Faculty of Natural Sciences, Konstantin Preslavski University of Shumen, Bulgaria Ivayla.Kuleva@mu-varna.bg
} 


\section{Materials and Methods}

\section{Studied area and soil sampling}

The study area in the present investigation is City Park in Shumen (CP), located in northeastern part of Bulgaria. Soil samples from CP (SCP) were collected during August 2015 under dry weather conditions. The latitude and longitude at sampling site were recorded using a handheld global

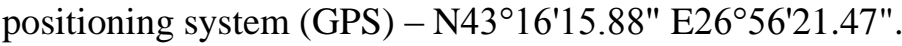

Sampling was provided by digging soil to depth of 0-10 $\mathrm{cm}$ (soil horizon A). Ten topsoil sub-samples were taken and bulked to give a composite sample. Sub-samples were taken in an 'S-shape' pattern at a distance of $5 \mathrm{~m}$. The samples were air-dried at room temperature in laboratory to constant weight, pulverized and then sieved to $<1 \mathrm{~mm}$ particle size.

\section{Allium cepa-test}

The onion bulbs were purchased from a biofarm certified to the BCS Öko Garantie; GLOBALG.A.P and IFS Food. The outer scales of the bulbs and the old dry roots were removed without destroying the root primordia. The bulbs were kept for root germination in deionized water for $24 \mathrm{~h}$. Bulbs with new roots with length of $1.5 \mathrm{~cm}$ were placed on soil:water suspension $(25: 1)$ and were allowed to root for $24 \mathrm{~h}$ at $25 \pm 1{ }^{\circ} \mathrm{C}$. The root tips were washed thoroughly with distilled water, fixed in Clarke's fixative (95\% ethanol: acetic acid glacial, 3:1) for 90 minutes and hydrolyzed in $1 \mathrm{~N} \mathrm{HCl}$ for 8 min and in $45 \%$ acetic acid for $60 \mathrm{~min}$ at room temperature. Then they were stained for $90 \mathrm{~min}$ in $1 \%$ aceto-orcein and the terminal root tips $(1-2 \mathrm{~mm})$ were excised and squashed in $45 \% \mathrm{CH}_{3} \mathrm{COOH}$. Each soil sample and control group consisted of 9 meristems from 3 bulbs. At least 1000 cells of each root meristem were analyzed. The mitotic index was determined as a ratio between the number of cells in mitosis and the total number of analyzed cells, expressed as a percentage. The index of each phase of mitotic division was calculated as a ratio between the cell number in the respective period and the number of dividing cells. The frequency of aberrant cells was calculated as a percentage of the total number of analyzed cells. The following abnormalities were scored: mitotic cells with chromosome bridges, fragments, vagrant chromosomes, multipolar anaphase/telophase, diagonal spindle, C-mitosis and interphase cells with micronuclei or two nuclei.

Statistical analysis

Results were expressed as the mean \pm standard deviation (SD), and significance was analyzed using Student's t-test where significance was accepted at $\mathrm{P} \leq 0.05$.

\section{Results and discussion}

Effects of a soil sample from CP on mitotic index and phase indices in root meristematic cells of Allium cepa L. are summarized in Table 1. The mitotic index decreased in comparison with the negative control. The lower mitotic division could be associated with various factors (as listed by Lamsal et al., 2010): inhibition of protein synthesis, influence on enzyme function, reduction of oxidative phosphorylation. Several checkpoints in mitotic cycle ensure proper distribution of genetic material. If there is DNA damage or inhibition of DNA synthesis, the cells are blocked in $\mathrm{G}_{2}$ phase (Selmi et al., 2014). Inhibition of mitotic activity is accepted as an indication of a cytotoxic effect (Olorunfemi et al., 2011). The treatment with soil suspension changed the mitotic phase distribution. The notable effect was a decrease of the telophase index. Changes in the proportion of mitotic phases also indicate the occurrence of a cytotoxic effect (Illbaş et al., 2011).

\begin{tabular}{|c|c|c|c|c|c|}
\hline Sample & $\begin{array}{c}\text { Mitotic index } \\
(\% \pm S D)\end{array}$ & $\begin{array}{l}\text { Prophase index } \\
\qquad(\% \pm S D)\end{array}$ & $\begin{array}{c}\text { Metaphase index } \\
(\% \pm S D)\end{array}$ & $\begin{array}{c}\text { Anaphase index } \\
(\% \pm S D)\end{array}$ & $\begin{array}{c}\text { Telophase index } \\
(\% \pm S D)\end{array}$ \\
\hline Control & $5.51 \pm 0.76$ & $34.31 \pm 14.48$ & $20.86 \pm 6.42$ & $11.89 \pm 8.15$ & $32.94 \pm 9.65$ \\
\hline SCP & $4.14 \pm 1.06^{*}$ & $42.15 \pm 10.24$ & $25.65 \pm 6.85$ & $14.40 \pm 4.83$ & $17.80 \pm 9.36^{*}$ \\
\hline \multicolumn{6}{|c|}{$\begin{array}{l}\mathrm{SCP} \text { - water suspension of soil from City Park of Shumen; Control - deionized water. Data are expressed as means } \pm \mathrm{SD} \\
\text { (standard deviation), } * \mathrm{P} \leq 0.05 \text {. }\end{array}$} \\
\hline
\end{tabular}

Exposure to soil sample increased $\sim 2.5$-fold the percent of chromosome aberrations in comparison to negative control (Table 2). Different kinds of mitotic abnormalities were observed (Figure 1). 
Diagonal metaphases and anaphases were the most frequent abnormalities. The occurrence of mitotic cells with diagonal position of spindle upon treatment with different compounds were reported in other studies (Bhatta and Sakya, 2008; Lamsal et al., 2010; Tripathy et al., 2013). Presence of vagrant chromosomes was notable in the treated cells. Vagrant chromosomes served as a sign of spindle disturbances (Yildiz and Arikan, 2008). C-mitoses and bridges in ana-telophase also were scored. Disturbed metaphases may be caused by inhibition of spindle formation (Selmi et al., 2014). Bridges may be consequence of DNA breaks (Maluszynska and Juchimiuk, 2005). Fragments and multipolar anaphases were not detected. As can be seen, soil samples caused spindle disturbances (vagrant chromosomes and disturbed metaphases and anaphases) rather than clastogenicity (bridges and fragments).

Treatment did not affect percent of micronuclei (extranuclear bodies of chromatin material) as compared to negative control (Table 2). On the other hand, soil sample from CP increased the number of binucleated cells $\sim 1.5$ fold. Binucleated cells result from failure of mitotic cells to complete cytokinesis and are accepted as a sign of cytotoxicity (Leme и Marin-Morales, 2009).

\begin{tabular}{|c|c|c|c|c|c|c|c|c|c|}
\hline \multirow[b]{2}{*}{ Sample } & \multicolumn{7}{|c|}{ Dividing cells } & \multicolumn{2}{|c|}{ Interphase cells } \\
\hline & $\begin{array}{c}\mathrm{B} \\
(\%)\end{array}$ & $\begin{array}{c}\mathrm{V} \\
(\%)\end{array}$ & $\begin{array}{c}\mathrm{F} \\
(\%)\end{array}$ & $\begin{array}{l}\mathrm{MP} \\
(\%)\end{array}$ & $\begin{array}{l}\mathrm{CM} \\
(\%)\end{array}$ & $\begin{array}{l}\text { DS } \\
(\%)\end{array}$ & $\begin{array}{c}\text { Total } \\
(\% \pm S D)\end{array}$ & $\begin{array}{c}\text { Micronuclei } \\
(\% \pm S D)\end{array}$ & $\begin{array}{c}\text { Two nuclei } \\
(\% \pm S D)\end{array}$ \\
\hline Control & 0.58 & 2.73 & 0.00 & 0.00 & 0.00 & 2.73 & $6.04 \pm 4.71$ & $0.01 \pm 0.04$ & $0.25 \pm 0.15$ \\
\hline SCP & 1.05 & 4.45 & 0.00 & 0.00 & 3.14 & 6.28 & $14.92 \pm 6.67 *$ & $0.01 \pm 0.04$ & $0.38 \pm 0.39$ \\
\hline
\end{tabular}

Source: Authors

Figure 1: Aberrations induced by soil sample in Allium cepa root tips: A - bridge; $\mathrm{B}$-vagrant chromosome in anaphase; C - diagonal anaphase; D - C-mitosis; $\mathrm{E}$ - micronucleus in interphase cell; $\mathrm{F}$ - binucleated cell.
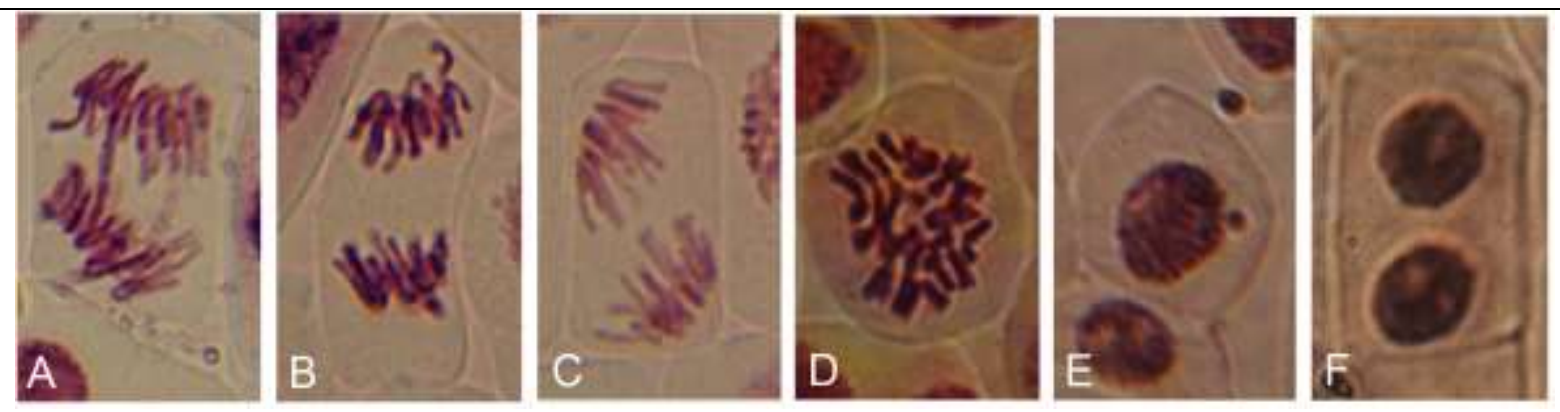

Source: Authors

Studies on soil pollution could contribute to a municipal policy on environmental management (Žigová et al., 2008). Since soil pollutants can have harmful effect on human health, there is a necessity to find out proper bioindicators for ecotoxicological analyses (Fontanetti et al., 2011). Present study confirmed other data that Alium cepa-test can be recommended for detection of cytotoxicity and genotoxicity of complex mixtures (Fiskesjö, 1993; Leme and Marin-Morales, 2009;

Tedesco and Laughinghouse IV, 2012). In our study, we compared effects of soil samples from CP on root meristematic cells with those of deionized water (as a negative control). The decline of the mitotic activity, changes in the proportion of mitotic phases, various mitotic abnormalities and binucleated interphase cells revealed cytotoxic and genotoxic effects. These observations indicate the existence of a health risk for people.

\section{Conclusion}

Established cytotoxicity and genotoxicity of soil sample from City Park revealed a potential risk to park users. Our study confirmed that bioassays could provide basic information about hazards of complex mixtures like soil. Further analyses on soils in City Park should be provided, since positive results from Allium-test serve as an alarm. 


\section{Acknowledgements}

This work has been supported by the Bulgarian Ministry of Education and Science, grant no. RD-08125/06.02.2017.

\section{References}

Bhatta, P. and Sakya, S.R. (2008). Study of mitotic activity and chromosomal behaviour in root meristem of Allium cepa L. treated with magnesium sulphate. Ecoprint, 15:83-88. http://www.nepjol.info/index.php/ECO/article/viewFile/1947/1802

Chahal, V., Nagpal, A., Pakade, Y.B. and Katnoria, J.K. (2014). Ecotoxicological studies of soil using analytical and biological methods: a review. IJIRSE, 8(3):302-318. http://waset.org/publications/9998465/ecotoxicological-studies-of-soilusing-analytical-and-biological-methods-a-review

Corneanu, M., Corneanu, G.C., Cojocaru, L. and Gămăneci, G. (2009). The evaluation of soil genotoxicity by modified Allium test. Muzeul Olteniei Craiova. Oltenia. Studii şi comunicări. ŞtiinţeleNaturii, 25:235-242. http://biozoojournals.ro/oscsn/cont/25/Ec01-Corneanu.pdf

Fiskesjö, G. (1993). The Allium test in wastewater monitoring. Environmental Toxicology, 8(3):291-298. doi:10.1002/tox.2530080306

Fontanetti, C.S., Nogarol, L.R., de Souza, R.B., Perez, D.G. and Maziviero, G.T. (2011). Bioindicators and biomarkers in the assessment of soil toxicity. In S. Pascucci (Ed.), Soil Contaminat, 144-168. doi:10.5772/25042

Galušková, I., Borůvka, L. and Drábek, O. (2010). Urban Soil Contamination by Potentially Risk Elements Soil and Water Research, 6(2):55-60.

İlbaş, A.I., Gönen, U., Yilmaz, S. and Dadandi, M.Y. (2012). Cytotoxicity of Aloe vera gel extracts on Allium cepa root tip cells. Turkish Journal of Botany, 36:263-268. doi:10.3906/bot-1102-5

Kabisch, N. and Haase, D. (2013). Green spaces of European cities revisited for 1990-2006. Landscape and Urban Planning, 110:113-122

Karim, Z., Qureshi, B.A., Mumtaz, M. and Qureshi, S. (2014). Heavy metal content in urban soils as an indicator of anthropogenic and natural influences on landscape of Karachi. A multivariate spatio-temporal analysis. Ecological Indicators, 42:20-31. doi:10.1016/j.ecolind.2013.07.020

Lamsal, K., Ghimire, B.K., Sharma, P., Ghimiray, A.K., Kim, S.W., Yu, C.Y., Chung, I.M., Lee, Y.S., Kim J. and Shakya, S.R. (2010). Genotoxicity evaluation of the insecticide ethion in root of Allium cepa L. African Journal of Biotechnology, 9(27):4204-4210. http://www.ajol.info/index.php/ajb/article/view/82625

Leme, D.M. and Marin-Morales, M.A. (2009). Allium cepa test in environmental monitoring: a review on its application. Mutation. Research, 682:71-81. doi:10.1016/j.mrrev.2009.06.002

Ljung, K., Selinus, O. and Otabbong, E. (2006). Metals in soils of children's urban environments in the small northern European city of Uppsala. Science of the Total Environment, 366:749-759.

Luo, X.S., Ding, J., Xu, B., Wang, Y.J., Li, H.B. and Yu, S. (2012). Incorporating bioaccessibility into human health risk assessments of heavy metals in urban park soils. Science of the Total Environment, 424:88-96.

doi:10.1016/j.scitotenv.2012.02.053

Maluszynska, J., Juchimiuk, J. (2005). Plant genotoxicity: a molecular cytogenetic approach in plant bioassays. Arhives of Industrial Hygiene and Toxicology, 56:177-184. https://core.ac.uk/download/pdf/14375079.pdf

Monarca, S., Feretti, D., Zerbini, I., Alberti, A., Zani, C., Resola, S., Gelatti, U. and Nardi, G. (2002). Soil contamination detected using bacterial and plant mutagenicity tests and chemical analyses. Environmental. Research. Sect. A, 88:64-69. doi:10.1006/enrs.2001.4317

Moosavi, M.H. and Zarasvandi, A. (2009). Geochemistry of urban soils in the Masjed-i-Soleiman (MIS) city, Khuzestan province, Iran. Environmental Marks. Research Journal of Environmental Sciences, 3:392-399. DOI: 10.3923/rjes.2009.392.399 URL: http://scialert.net/abstract/?doi=rjes.2009.392.399

Olorunfemi, D.I., Okoloko, G.E., Bakare, A.A. and Akinboro, A. (2011) Cytotoxic and Genotoxic Effects of Cassava Effluents using the Allium cepa assay. Research Journal of Mutagenesis, 1(1):1-9.

Owen, N., Sparling, P.B., Healy, G.N., Dunstan, D.W. and Matthews, C.E. (2010). Sedentary behavior: emerging evidence for a new health risk. Mayo Clinic Proceedings, 85(12):1138-1141. http://doi.org/10.4065/mcp.2010.0444

Science Communication Unit, (2013). Soil Contamination: Impacts on Human Health. University of the West of England, Bristol. Science for Environment Policy. In depth Report. Report produced for the European Commission DG Environment, 5:1-29. http://ec.europa.eu/science-environment-policy

Selmi, S.S., Abdelfattah, T.S. and Mostafa, F.D. (2014). Deregulation of mitosis progression and cytotoxic effect triggered in Allium Cepa L. roots by Rubus Sancatus Schreber Extract. Life Science Journal, 11(11):1047-1058. http://www.lifesciencesite.com/lsj/life1111/181_27482life111114_1047_1058.pdf

Soodan, R.K., Pakade, Y.B., Nagpal, A. and Katnoria, J.K. (2014). Analytical techniques for estimation of heavy metals in soil ecosystem: A tabulated review. Talanta, 125:405-410. http://dx.doi.org/10.1016/j.talanta.2014.02.033

Tedesco S.B. and Laughinghouse IV, H.D. (2012). Bioindicator of Genotoxicity: the Allium cepa test. Environmental Contamination. In J. Srivastava, (Ed.), InTech, 137-156. doi:10.5772/31371

Tripathy, S.K., Bijayinee, S., Samad, I. and Das, R.K. (2013). Endosulfan: a potential genotoxicant on Allium cepa root tip cells. Journal of Agricultural Biotechnology and Sustainable Development, 5(2):29-35. doi:10.5897/JABSD12.0001 
Watanabe, T. and Hirayama, T. (2001). Genotoxicity of Soil. Journal of Health Science, 47(5):433-438.

White, P.A. and Claxton, L.D. (2004). Mutagens in contaminated soil: a review. Mutation Research, 567(2-3):227-345.

Yang, J. and Zhang, G. (2015). Formation, characteristics and eco-environmental implications of urban soils: a review. Journal Soil Science and Plant Nutrition, 61:30-46. http://dx.doi.org/10.1080/00380768.2015.1035622

Yildiz, M. and Arikan, E.S. (2008). Genotoxicity testing of quizalofop-P-ethyl herbicide using the Allium cepa anaphasetelophase chromosome aberration assay. Caryologia, 61:45-52. doi:10.1080/00087114.2008.10589608

Žigová, A., Št’astný, M., Ložek, V. and Šrein, V. (2008). Soil cover of the protected areas of Prague as an indicator of environmental changes. Acta Research Reports, 17:21-25.

https://www.irsm.cas.cz/materialy/acta_content/2008_17/3_Zigova.pdf 